TECHNICAL TRANSACTIONS 1/2018

ENVIRONMENTAL ENGINERING

DOI: $10.4467 / 2353737$ XCT.18.010.7961 SUBMISSION OF THE FINAL VERSION: 5/1/2018

\author{
Andrzej Kotowski (andrzej.kotowski@pwr.edu.pl) \\ Monika Nowakowska (monika.nowakowska@pwr.edu.pl) \\ Department of Water and Sewage, Faculty of Environmental Engineering, Wrocław \\ University of Science and Technology
}

\title{
STANDARDS FOR THE DIMENSIONING AND ASSESSMENT OF RELIABLE OPERATIONS OF AREA DRAINAGE SYSTEMS UNDER CONDITIONS \\ OF CLIMATE CHANGE
}

STANDARDY WYMIAROWANIA I OCENY NIEZAWODNOŚCI DZIAŁANIA SYSTEMÓW ODWODNIEŃ TERENÓW W WARUNKACH ZMIAN KLIMATU

\begin{abstract}
Contemporary area drainage dimensioning standards are presented in this paper. Hazards for drainage systems arising from climate changes are discussed and trends of changes in the precipitation structure are presented using the example of data obtained from Wroclaw. The need for changes within precipitation scenarios is indicated for modelling overflow in channels and a research methodology and assessment criteria of the degree of reliability of the drainage system are proposed. Results are presented of an analysis of the operation of the rainwater drainage system in the Gaj and Tarnogaj housing estates in Wroclaw - these were conducted using a calibrated hydrodynamic model in SWMM software. It was proved that the examined system does not meet the standards of PN-EN 752:2008, DWA-A 118:2006 and Merkblatt no. 4.3/3:2009 with regard to instances of flooding from channels and that adaptation to climate change is required.
\end{abstract}

Keywords: urban hydrology, storm water drainage, dimensioning, modelling, overflow, flooding from channels

\section{Streszczenie}

Przedstawiono współczesne standardy wymiarowania odwodnień terenów. Omówiono zagrożenia dla systemów kanalizacyjnych wynikające ze zmian klimatu i zaprezentowano trendy zmian w strukturze opadów, na przykładzie danych z Wrocławia. Wskazano na potrzebę zmiany scenariuszy opadów do modelowania nadpiętrzeń w kanałach oraz zaproponowano metodykę badań i kryteria ocen stopnia niezawodności kanalizacji. Przedstawiono wyniki analizy działania kanalizacji deszczowej na osiedlach Gaj i Tarnogaj we Wrocławiu, przeprowadzonej na skalibrowanym modelu hydrodynamicznym w programie SWMM. Wykazano, że badany system nie spełnienia standardów PN-EN 752:2008, DWA-A 118:2006 i Merkblatt Nr. 4.3/3:2009 odnośnie wylewów z kanałów i wymaga dostosowania do zmian klimatu.

Słowa kluczowe: hydrologia miejska, kanalizacja deszczowa, wymiarowanie, modelowanie, nadpiętrzenia, wylewy z kanałów 


\section{Introduction}

In Poland, like in other countries in Europe and in the world, changes to the climate are observable - these manifest themselves in, for example, the growing intensity of precipitations and the frequency of the occurrence of extreme events such as urban floods in the form of flooding from channels [1]. The reason for climate warming (the so-called greenhouse effect caused by, among other factors, the emission of steam and $\mathrm{CO}_{2}$ to the atmosphere) has not been completely identified and still remains a matter of disagreement. Unquestionably still, the observed increase in air temperature significantly affects the circulation of water in the hydrological cycle: vaporisation - condensation - precipitation. According to the report by the Intergovernmental Panel on Climate Change (IPCC: 2007) [2], in the period 1960-2005 alone, the average annual temperature increase was $0.74^{\circ} \mathrm{C}$. As a result, over the period 1901-2010, the levels of seas and oceans rose by an average of $0.19 \mathrm{~m}$ (IPCC: 2014) [3]. According to forecasts based on the global climate model, the air temperature may rise by anything from $1.7^{\circ} \mathrm{C}$ to as much as $4.4^{\circ} \mathrm{C}$ this century, and each degree of temperature increase is expected to be accompanied by a global growth in precipitation intensity by approximately 7\% [4]. In central European countries, for instance, catastrophic flooding will occur more frequently than once every 50 years on average [5].

Floods threaten most Polish cities which are located in river valleys (river floods) and in the coastal zone (storm floods). On the other hand, local area flooding (urban floods) may occur everywhere, most often as a result of sudden convective precipitation, a long-lasing front or low-pressure rainfall. This is exacerbated by a large density of urban development and a large sealed surface area - this leads to a significant limitation in rainfall water infiltration to the ground. Hazards and losses generated by urban floods are manifested by local flooding from rain channels or combined sewers (flooding of streets, estates and basements - Fig. 1), as a consequence of, among other factors, an inadequate flow capacity and a lack of retention in the existing drainage systems [6].
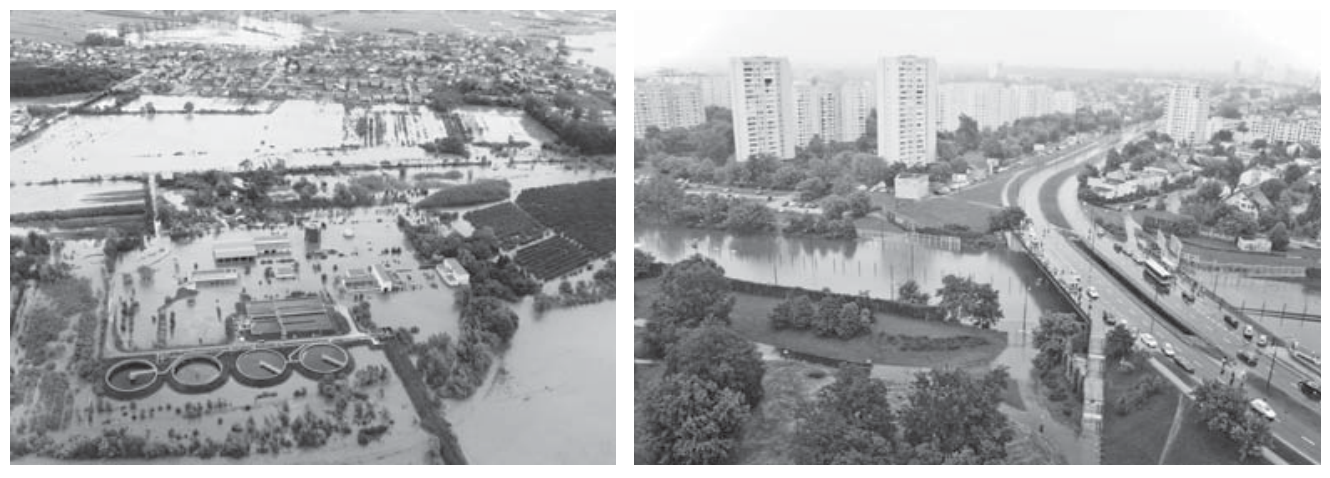

Fig. 1. Urban floods [6]

A considerable proportion of rainfall water drainage systems built in Poland after World War II have been dimensioned with methods that are unsuitable in the present day (MGN and MSN), using the out-dated Blaszczyk formula for rain intensity (based on precipitation from 
the turn of the $19^{\text {th }}$ and $20^{\text {th }}$ centuries), which makes them unlikely to fulfil the requirements of the most recent standard PN-EN 752:2008 [7] with regard to acceptable frequency of flooding from channels, especially in the future. This generates a need to examine the degree of hydraulic reliability of systems which have been dimensioned in such a manner in hydrodynamic modelling and undertake the appropriate remedial actions, such as those suggested in this paper.

\section{Contemporary dimensioning standards for urbanised area drainage}

The risk of the occurrence of phenomena with unfavourable consequences is defined as a combination of the probability of occurrence and measurement of their adverse effects. Under conditions of climatic change, anticipating the risk of hazards from flooding from channels is vital for rational water management in cities. It especially applies to the basis for dimensioning drainage systems for urbanised areas, i.e. rainwater drainage or combined drainage $[6,8]$. According to the Act of 12 September 2002 on standardisation, Polish (PN) and international standards (EN and ISO) should be regarded, as compare to current technical design guidelines (WTP) or published results of the most recent research works (e.g. with regard to drainage system dimensioning methods). The present legal condition puts a greater responsibility on the designers, including the obligation to design safely, i.e. in accordance with the art of construction resulting from the best available technical knowledge: BAT - Best Available Techniques; BMP - Best Management Practices; LID - Law Impact Development; ZWT - Principles of Technical Knowledge.

It is, however, not possible to ensure fully reliable area-drainage operations owing to the stochastic nature of precipitation. We can only aim to dimension them safely, i.e. adjust the systems to accept the maximum forecasted rainfall water streams, with frequency of incidence equal to the acceptable frequency of the occurrence of flooding onto the area surface. This also applies to future drainage basin loads resulting from precipitation exacerbated by climate change. The Polish standard PN-EN 752:2008 limits the acceptable frequency of flooding from the drainage system to rare frequencies of incidence (Table 1). Thus, this is a type of 'social

Table 1. Frequencies of calculated rain and acceptable frequencies of flooding from channels according to PN-EN 752:2008

\begin{tabular}{|c|c|c|}
\hline \multirow{2}{*}{ Location } & \multicolumn{2}{|c|}{ Frequencies of: } \\
\cline { 2 - 3 } & precipitation & floodings \\
\cline { 2 - 3 } & \multicolumn{2}{|c|}{$[1$ in C years $]$} \\
\hline rural areas & 1 per 1 & 1 per 10 \\
\hline residential areas & 1 per 2 & 1 per 20 \\
\hline city centres, services and industrial areas & 1 per 5 & 1 per 30 \\
\hline $\begin{array}{c}\text { underground transport facilities, passages and } \\
\text { crossings under streets, etc. }\end{array}$ & 1 per 10 & 1 per 50 \\
\hline
\end{tabular}


contract' for obligatory compliance. On the other hand, for drainage system dimensioning, it accepts the adoption of smaller values of the calculated frequencies of precipitation; however, no overload may then occur in the operation of the systems, e.g. work under pressure. This generates a need to select channels for incomplete filling, i.e. with a flow capacity reserve in case of less frequent rains. According to PN-EN 752:2008 the recommended frequency of calculated rain is a facultative.

However, determination of the relationship between the frequency of calculated rain and the frequency of flooding is not possible, especially when the drainage system is only at the design stage. Reliability of operation of drainage systems may thus be examined only by means of hydrodynamic modelling. To determine the degree of reliability of the drainage system, the DWA-A 118:2006 [9] guidelines are of help by introducing the notion of frequency of overflow under the ground level for verifying calculations by means of modelling. As a result, it is possible to determine the overload condition which is closest to potentially flooding occurring later (Table 2).

Table 2. Acceptable frequencies of overflow for verifying calculations of the newly designed or modernised drainage systems according to DWA-A 118:2006

\begin{tabular}{|c|c|}
\hline Location & $\begin{array}{c}\text { Frequency of overflows } \\
{[\mathbf{1} \text { in C years }]}\end{array}$ \\
\hline rural areas & 1 per 2 \\
\hline residential areas & 1 per 3 \\
\hline city centres, services and industrial areas & less frequently than 1 per 5 \\
\hline underground transport facilities, \\
passages and crossings under streets, etc.
\end{tabular}

The idea of complete water drainage of urbanised areas is presently being abandoned in Europe, i.e. carrying away all rainfall waters (rain and thaw waters) to rain drainage or combined drainage systems in favour of draining only water originating from contaminated sealed surfaces (after initial treatment). In accordance with the principle of sustainable development, proper water management in urbanised areas should mainly consist of the management of as much a volume of 'clean' rainfall waters as possible, so as to decrease and delay surface water run-off to receivers, and prevent reduction in the levels of underground waters in cities. This is achieved with the use of retention, infiltration and evapotranspiration processes, in such structures as: storage-infiltration reservoirs, natural terrain basins or the recently promoted so-called green roofs [10-13]. At the same time, excessive sealing of area surfaces should generally be avoided, for example, openwork sealing should be used. When dimensioning new rain channels, their minimum diameter should be increased from the presently required $D_{\min }=0.30 \mathrm{~m}$ to $0.40 \mathrm{~m}$ - according to work [6]. Similarly, it becomes necessary to increase the number of street inlets for rainfall, and thus reduce their spacing from the presently recommended $\leq 30 \mathrm{~m}$ to $\leq 20 \mathrm{~m}$ - depending on the road class and longitudinal and transverse slopes of the roadway - on the basis of research by Edel \& Suligowski [14]. These and other remedies shall prove effective in the future. 


\section{Trends of changes in the frequency of occurrence of intensive precipitation}

Drainage systems reliability tests, recommended by standard PN-EN 752 from 2008 are rarely conducted in Poland - these are even required by the law according to the Regulation of the Minister of Environment of 2014 with regard to the verification of the frequency of the operation of storm overflows (in cities with RLM>100000). The reason for this failure to conduct the reliability tests stems mainly from the absence of relevant input databases (monitoring of precipitation and flows in the network) and an insufficient methodological basis for the tests. Therefore, it is of worth to improve the tools for the mathematical modelling of area drainage systems on the basis of local databases obtained through monitoring $[15,16]$.

Referring to precipitation as reference precipitation for the design and modelling of the operation of area drainage - according to contemporary standards PN-EN752:2008 (Table 1) and DWA-A1 18:2006 (Table 2), growth is forecast in their intensity in the future as a result of climate changes. The basis for the assessment of the future hazards is thus the selection of appropriate scenarios - relating to the frequency of precipitation with regard to the present patterns, such as: IDF (Intensity-Duration Frequency) or DDF (Depth-Duration Frequency). Probability models of maximum precipitation are applied here, e.g. the Bogdanowicz - Stachý model, which was established on the basis of Polish national rain measurements for 20 IMGW meteorological stations in the period 1960-1990 [17]:

$$
h_{\max }=1.42 t^{0.33}+\alpha(R, t) \cdot(-\ln p)^{0.584}
$$

where:

$h_{\max }-$ maximum precipitation amount $(\mathrm{mm})$;

$t$-rain duration: $t \in[5 ; 4320](\mathrm{min})$;

$p$ - probability of precipitation elevation: $p=1 / C \in(0 ; 0.5](-)$;

$\alpha$-scale parameter dependent on the region of Poland $(R)$ and rainfall duration $(t)$.

In Poland, due to climatic warming, the structure of regional precipitation is projected to substantially change for the period 2071-2100, taking the years 1951-2009 as the starting measurement period - according to the monograph [18]. These changes will manifest themselves, among other ways, in the fact that short (single) intensive rainfall will be subject to rearrangement into longer episodes that may even last a few days with the total amount of precipitation being much higher than before. Because of the systematic increase in air temperature, more extreme rainfall phenomena will occur in the future - this will cause even greater economic and social losses than now. Since drainage systems are usually built with the life perspective of a minimum of 50-100 years, consideration for these forecasts is vital today in order to safely dimension such systems for the future [6].

Considering the present state of knowledge about change of precipitation trends until 2100 , should be made by correcting intensity curves (IDF) - for the present frequency of incidence, or changing the frequency of incidence of precipitation in the future - for the present intensities (Table $1 \& 2$ ) [19-21]. Staufer et al. [21] suggested adjustment in the 
frequency of precipitation currently adopted for the verification of overflow and flooding according to standard DWA-A118:2006 - this is presented in Table 3.

Table 3. Adjustments to DWA-A118:2006 with regard to precipitation scenarios for the identification of future drainage system overload according to Merkblatt No. 4.3/3:2009

\begin{tabular}{|c|c|c|}
\hline \multirow{2}{*}{ Location } & \multicolumn{2}{|c|}{ Frequency of precipitation for simulation of: } \\
\cline { 2 - 3 } & overflow & flooding \\
\cline { 2 - 3 } & \multicolumn{2}{|c|}{$[$ once every $C$ years] } \\
\hline rural areas & 3 instead of 2 & 50 instead of 10 \\
\hline residential areas & 5 instead of 3 & 100 instead of 20 \\
\hline city centres, services and industrial areas & 10 instead of 5 & 100 instead of 30 \\
\hline
\end{tabular}

For instance, for residential areas, Staufer et al. suggested a precipitation scenario of $C=5$ years (instead of $C=3$ years according to Table 2 ) for verification of the presence of future overflow, and a precipitation scenario of $C=100$ years to provide an acceptable frequency of flooding once every 20 years (according to Table 1). Based on this, the Land Office for Bavaria Environment issued a recommendation (Merkblatt no. 4.3/3:2009 [22]) with regard to changes in the frequency of precipitation for the identification of future overloads in the drainage system (Table 3).

Further research concerning scenarios of growing precipitation intensity in the future is necessary [23-25]. For instance, in the work [25], in order to examine local trends of changes in the frequency of the occurrence of intensive precipitation in Wrocław, the analysis covered precipitation amounts time series from the last five decades (1960-2009), in 16-time intervals of duration $t \in[5,4320]$ in minutes. The data came from IMGW-PIB WroctawStrachowice meteorological station. To conduct the tests, a local probabilistic model of maximum precipitation was used $[26,27]$ :

$$
h_{\max }(t, p)=-4.58+7.41 t^{0.242}+\left(97.1 t^{0.0222}-98.7\right)(-\ln p)^{0.809}
$$

on the basis of which, threshold values of the ranges of the precipitation levels were calculated for the frequency of incidence: from once a year to once every 10 years. The maximum measured ranges of precipitation levels were then grouped into 4 classes of frequency of incidence with precipitation elevation, i.e.: $C \geq 1(p \leq 1), C \geq 2(p \leq 0.5), C \geq 5(p \leq 0.2)$ and $C \geq 10$ years $(p \leq 0.1)$. The examined trends of changes, described by linear regression, are specified in Table 4.

It seems from the conducted studies that a growing trend occurred in the period 19602009 in the amount of precipitation in 4 classes of the designed frequencies. Growth trends determined for the frequency of the occurrence of precipitation $C \geq 5$ years and $C \geq 10$ years (Table 4, Fig. 2) are statistically reliable. 
Table 4. Trends of changes in maximum precipitation amount in Wroclaw in the period 1960-2009

\begin{tabular}{|c|c|c|c|c|c|}
\hline $\begin{array}{c}\text { Frequency } \\
\text { of } \\
\text { precipitation }\end{array}$ & $\begin{array}{c}\text { Number of } \\
\text { items of data }\end{array}$ & $a$ & $b$ & $\begin{array}{c}\text { Value of } \\
\text { test } \mathrm{F}\end{array}$ & $\begin{array}{c}\text { Level of } \\
\text { significance, } \\
\%\end{array}$ \\
\hline$C \geq 1$ year & 804 & 33.0 & 0.0534 & 1.05 & 69 \\
\hline$C \geq 2$ years & 397 & 37.7 & 0.0986 & 1.31 & 75 \\
\hline$C \geq 5$ years & 198 & 37.3 & 0.323 & 5.43 & 98 \\
\hline$C \geq 10$ years & 108 & 38.2 & 0.524 & 6.63 & 99 \\
\hline
\end{tabular}
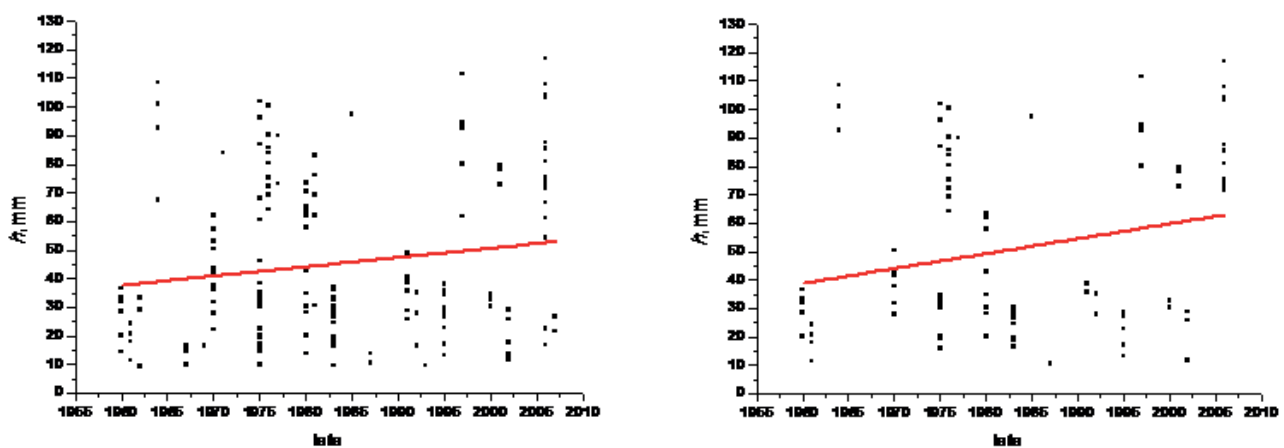

Fig. 2. Trends of changes in the range of precipitation levels for the frequency of incidence $C \geq 5$ years (on the left) and $C \geq 10$ years (on the right) in Wroclaw in the period 1960-2009

The growth trends of changes in the frequency of the occurrence of intensive precipitation as observed in Wroclaw are confirmed in monograph [18], where, on the basis of the climate model of Europe HadRM3-PRECIS and SRES A2 and B2 scenarios, likely precipitation intensity changes in Poland were determined for the time period 2071-2100, starting from the similar measurement period of 1951-2009. This suggests a need for changes in the frequency of precipitation, which is currently adopted as reference precipitation for the dimensioning and verification of drainage system overloads in Poland which are induced by climate change.

With calibrated hydrodynamic models of area drainage systems, in order to accommodate their expansion or modernisation, the frequency of precipitation should be changed in DWAA118:2006 to simulate the incidence of overflow, so as to ensure that they reflect the likely overload of the channels in the future. Specifically, it is suggested to check overflows for the present rains with frequencies of incidence: $C=3,5,10$ years (dependent upon the type of land development) - according to the recommendations of Merkblatt no. 4.3/3:2009 provided in Table 3. Supplementing these recommendations - for underground transport facilities, passages and crossings under streets, etc., due to the effects of hazards, it is recommended to adopt $\mathrm{C} \geq 50$ years according to [6]. 
Assuming a similar reasoning logic, in the case of no possibility to simulation of flooding from rain channels, eg in the of designing new drainage systems, the frequencies of rain (recommended by PN-EN 752:2008), should be increased accordingly - to the preserve in the future the acceptable frequency of incidence of flooding from channels. Proposed changes in PN-EN 752:2008 for facultative use are specified in Table 5, on the basis of paper [6].

Table 5. The proposed changes to PN-EN 752:2008 with regard to the frequencies of calculated rain in the case of no possibility to simulate flooding from channels [6]

\begin{tabular}{|c|c|}
\hline \multirow{2}{*}{ Location } & Frequencies of precipitation \\
\cline { 2 - 2 } & {$[1$ in C years $]$} \\
\hline rural areas & 2 instead of 1 \\
\hline residential areas & 5 instead of 2 \\
\hline city centres, services and industrial areas & 10 instead of 5 \\
\hline $\begin{array}{c}\text { underground transport facilities, passages and } \\
\text { crossings under streets, etc. }\end{array}$ & 50 instead of 10 \\
\hline
\end{tabular}

\section{Standards for the testing and assessment of the reliability of drainage systems}

The first stage in the identification of overloads of channels in the future should be the simulation of the operation of the existing or the newly-designed drainage system with regard to overflow. For instance, for urban drainage areas in the vicinity of residential buildings (total area $F>2 \mathrm{~km}^{2}$ ), in accordance with the previous recommendations of DWA-A118:2006 (Table 2), it was recommended to load rain channels with precipitation with a frequency of incidence of $C=3$ years and a duration at least twice as long as the time of flow in the network. Currently, according to Merkblatt no. 4.3/3:2009 (Table 3), it is recommended that simulations should relate to future drainage system load scenarios. For residential drainage areas, these are today's precipitations with the frequency of incidence of $C=5$ years for the verification of overflow and $C=100$ years to provide an acceptable frequency of floodings in the future according to PN-EN 752:2008 (Table 1). After assessment of the results of such simulations, a need may be observed for system adaptation in accordance with the forecasted growth of rainfall water runoff in streams in the future.

Reference parameters to demonstrate the need to adjust a given drainage system to climate changes may be, for example, the degree of flooding $(D F)$ and the specific flood volume $(S F V)[28]$. DF ratio is the ratio of the number of wells flooded to the land surface level $\left(N_{f}\right)$ to the general number of wells $(N)$ of a given system or its mutually related parts:

$$
D F=\sum N_{f} / \sum N
$$

SFV ratio (in $\mathrm{m}^{3} / \mathrm{ha}$ ) results from the calculated volume of flooding from channels $V$ (in $\left.\mathrm{m}^{3}\right)$ in relation to the sealed surface $\left(F_{s}\right)$ of a given basin (in ha): 


$$
S F V=\sum V / \sum F_{s}
$$

Threshold values of $D F$ and $S F V$ ratios should be individually agreed for a given system. For example, results of the assessment of the reliable operation of three drainage systems in North Rhine-Westphalia are specified in the work [28]. The examined drainage basins were located inside urban areas or city centres. To simulate overflow and flooding, precipitation with a frequency of incidence of $C=5$ years and extreme precipitation with a frequency of $C=100$ years has been adopted as the load of the channels. Based on this, threshold values were determined: $D F=0.33$ and $S F V=13 \mathrm{~m}^{3} /$ ha. Above of those values, systems already require of modernization. In the event of local system overloads being identified (according to the scenarios from Table 3), further risk analysis is necessary [29]. This can be made on the basis of GIS and/or in-situ assessments [30], and in the case of observing extensive overloads, additional simulation of the system operation becomes necessary in combination with a digital land model. A detailed analysis of the simulation results allows not only the marking out of flood land boundaries, but also specifying the depth of water, stream speed and water flow volume.

The suitability of the presented reliability testing methodology has been verified in the conditions of Wrocław in works [31-33]. For instance, the $\mathrm{PhD}$ thesis [33] presents an assessment of the degree of reliable operation of the rainwater drainage system in the Gaj and Tarnogaj housing estates in Wroclaw. The research was conducted on a calibrated hydrodynamic model in SWMM software for conditions of the present precipitation load and for the forecast load growth in the future. The channelled drainage area is $1.04 \mathrm{~km}^{2}$ (Fig. 3).

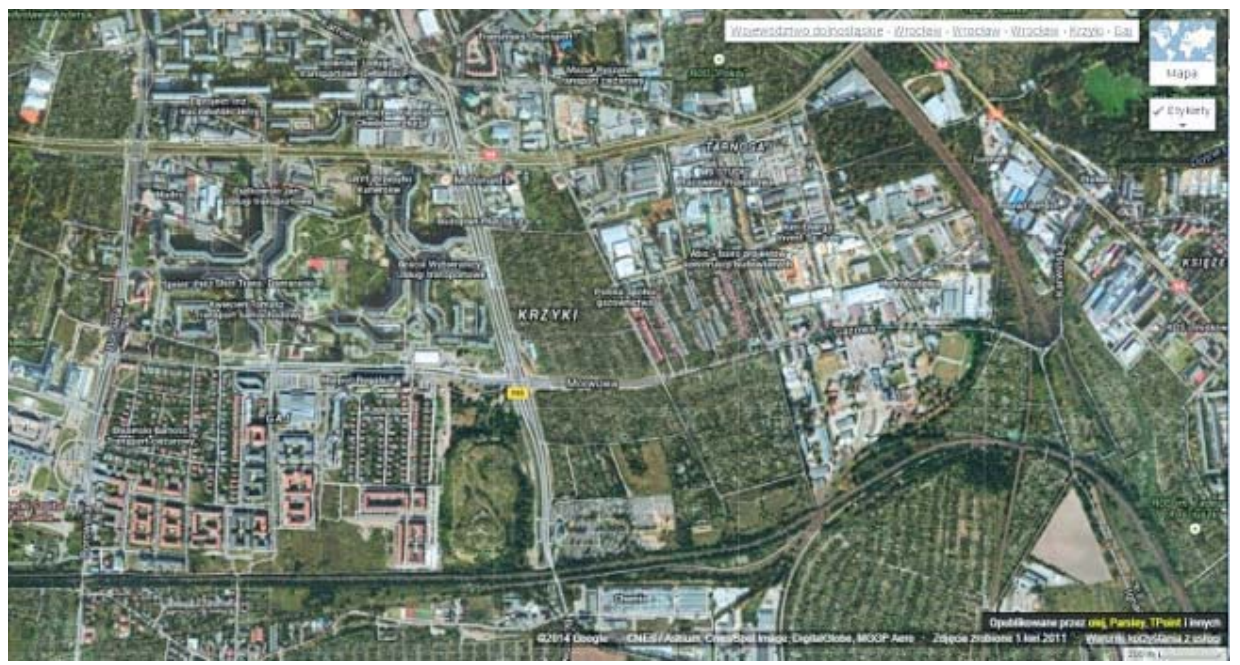

Fig. 3. Rainwater catchment area orthophoto map of the Gaj and Tarnogaj housing estates in Wroctaw

The total length of the catalogued rain channels was $17.730 \mathrm{~m}$, and the number of wells was 509. Seventy-five partial drainage basins were separated in the model $\left(F_{i, a v e r a g e}=1.39\right.$ ha, at $F_{i, \min }=0.22 \mathrm{ha}$ and $F_{i, \max }=5.34 \mathrm{ha}$ ). Using the analysis of clusters by the Ward method and 
the so-called box charts, the partial drainage basin hydraulic width $\left(W_{i}\right)$ was determined from formula [33]:

where:

$$
W_{i}=1.6 \sqrt{F_{i}}
$$

$F_{i}$ - partial drainage basin area, $\mathrm{m}^{2}$.

Calibrated on front and low-pressure precipitation, and then validated on convective precipitation, the hydrodynamic model of the examined drainage system had the following parameters: rain channel roughness coefficient $(n)$ was $0.020 \mathrm{~s} / \mathrm{m}^{1 / 3}$; sealed drainage basin surface roughness coefficient was $0.020 \mathrm{~s} / \mathrm{m}^{1 / 3}$, non-sealed surface roughness coefficient was $0.30 \mathrm{~s} / \mathrm{m}^{1 / 3}$; field retention height $(h)$ on sealed areas was $2.0 \mathrm{~mm}$, and on non-sealed areas it was $5.0 \mathrm{~mm}$. The agreed infiltration parameters in the Horton model are: initial infiltration intensity, $90 \mathrm{~mm} / \mathrm{h}$; final infiltration intensity, $10 \mathrm{~mm} / \mathrm{h}$; recession constant, $41 / \mathrm{h}$; ground total drying time, $7 \mathrm{~d}$. The scheme of the examined drainage network, created in SWMM software, is presented in Fig. 4.

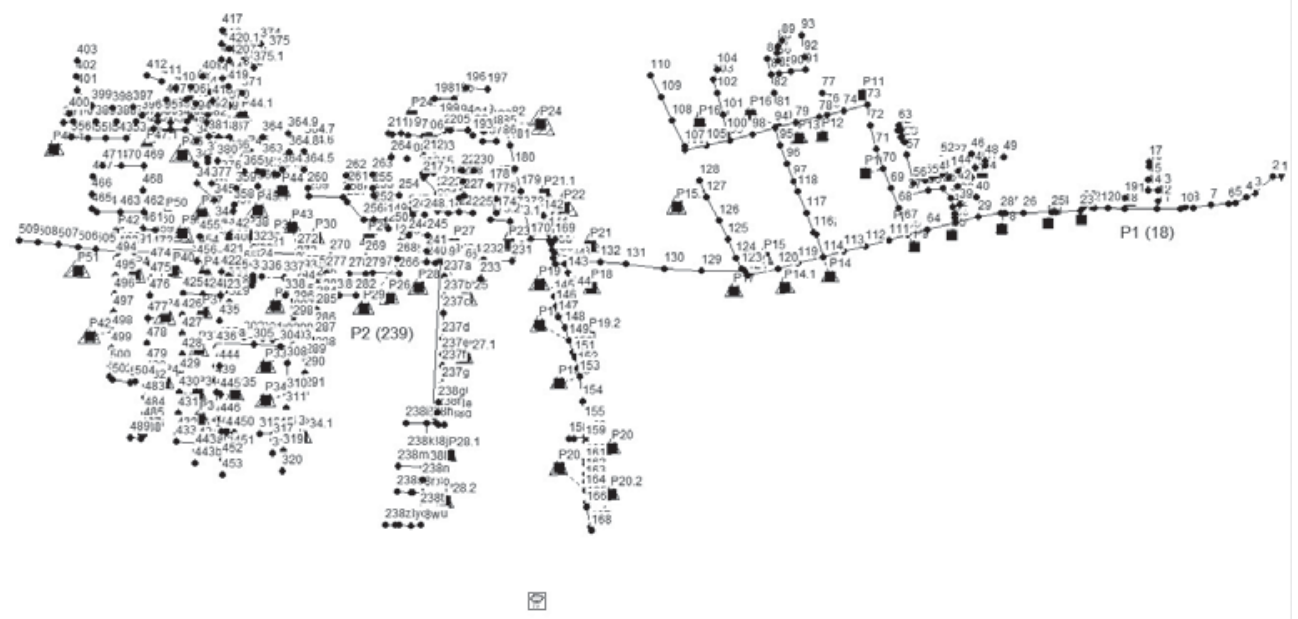

Fig. 4. Scheme of the examined rainwater drainage basin drainage system in SWMM software

Two convective precipitations were used as the drainage basin's load [33]:

- type II Euler method with the frequency of incidence in Wroctaw of $C=3$ years for the simulation of the present drainage basin's supply conditions (according to Table 2);

- the real rain, a heavy rain scenario with the frequency of incidence in Wroctaw of $C=5$ years for simulation of the drainage basin's supply conditions in the future

Real precipitation with an intensity of $34 \mathrm{~mm} / \mathrm{h}$ was registered on 19.07.2015 on an R05 rain meter, at a distance of $620 \mathrm{~m}$ from the centre of gravity of the examined drainage basin (Fig. 5). It was assumed that point overflooding, with a volume of over $200 \mathrm{~m}^{3}$, can create potential hazards. For example, assuming that water is dammed up to the level of roadway 
curbs $(0.15 \mathrm{~m})$, the range of flooding would then cover a surface area of $37 \mathrm{~m} \times 37 \mathrm{~m}=1369 \mathrm{~m}^{2}$ (i.e. approx. $10 \% F_{i, a v e r a g e}=1.39 \mathrm{ha}$ ). For drainage basin load with a model precipitation of $C=3$ years, the presence of 4 critical nodes was observed in the examined network with flooding above $200 \mathrm{~m}^{3}$ (Fig. 5). On the basis of Formula (3), the value of indicator $D F=0.16$ was calculated (as the ratio of the number of flooded wells $N_{f}=79$ to the total number of wells $N=509$ ). However, the specific flood volume according to Formula (4) is $S F V=19 \mathrm{~m}^{3} /$ ha (for $\Sigma V=1171 \mathrm{~m}^{3}$ and drainage basin sealed surface $F_{s}=61.5 \mathrm{ha}$ ). The calculated value of $S F V>13 \mathrm{~m}^{3} /$ ha, according to the quoted Siekmann \& Pinnekampf criteria [28], indicates no fulfilment of the requirement of standards PN-EN 752:2008 and DWA-A 118:2006 by the studied drainage system, and thus the need for its adaptation to the effects of climate change that are already happening.

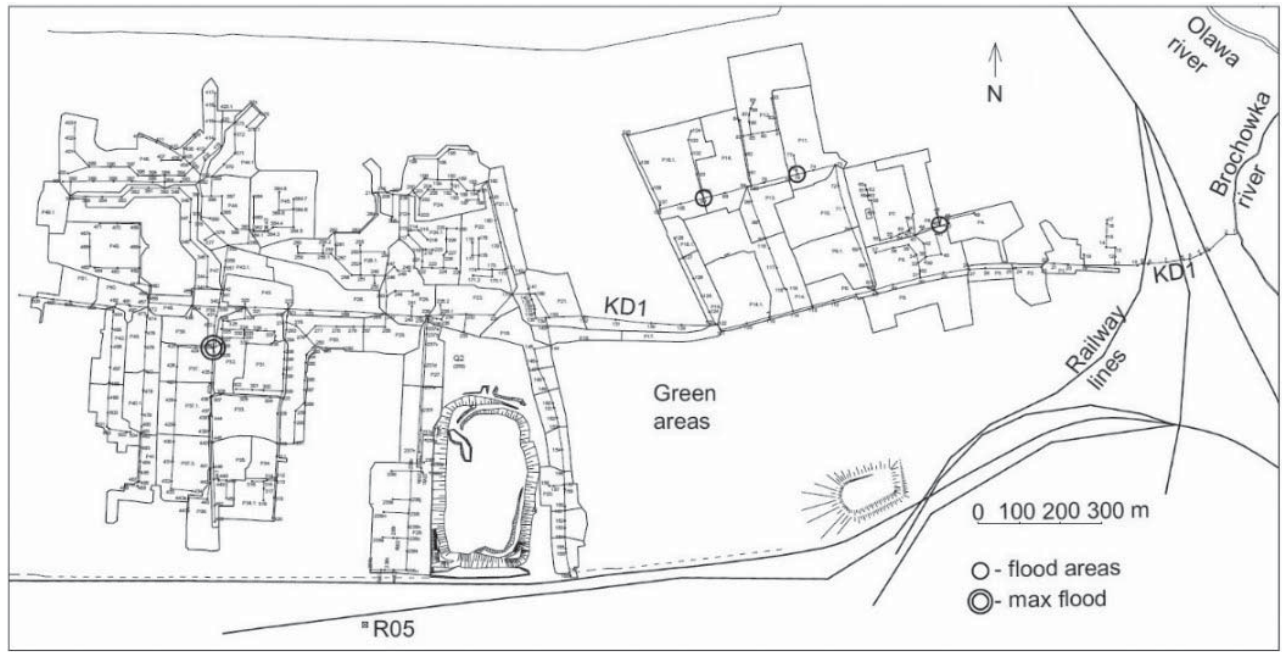

Fig. 5. Location of flooding from channels for Euler type II model precipitation of $C=3$ years

In the second stage of the research concerning the drainage basin's supply conditions in the future, i.e. during simulation of the drainage basin's load with precipitation of $C=5$ years, floodings were already observed in 8 network nodes. Degree of flooding was DF $=87 / 509$ $=0.17$, and the specific flood volume $S F V=2641 / 61.5=42.9 \mathrm{~m}^{3} / \mathrm{ha}$. Figure 6 presents the KD1 collector profile during the occurrence of maximum overflow and flooding: on twothirds of the length of the collector, rainwater flows under pressure, and on one-third of the length, there are critical points where the level of water reaches the ground level (like for the model precipitation).

As in model precipitation of $C=3$ years, in the case of real precipitation of $C=5$ years, the value of the indicator $S F V>13 \mathrm{~m}^{3} /$ ha indicated no fulfilment by the studied drainage system of the requirements of standards PN-EN 752:2008 and Merkblatt no. 4.3/3:2009, i.e. the need for its adaptation to climate changes in the future. Thus, there was no need to simulate the operation of the examined system of $C=100$ years. 


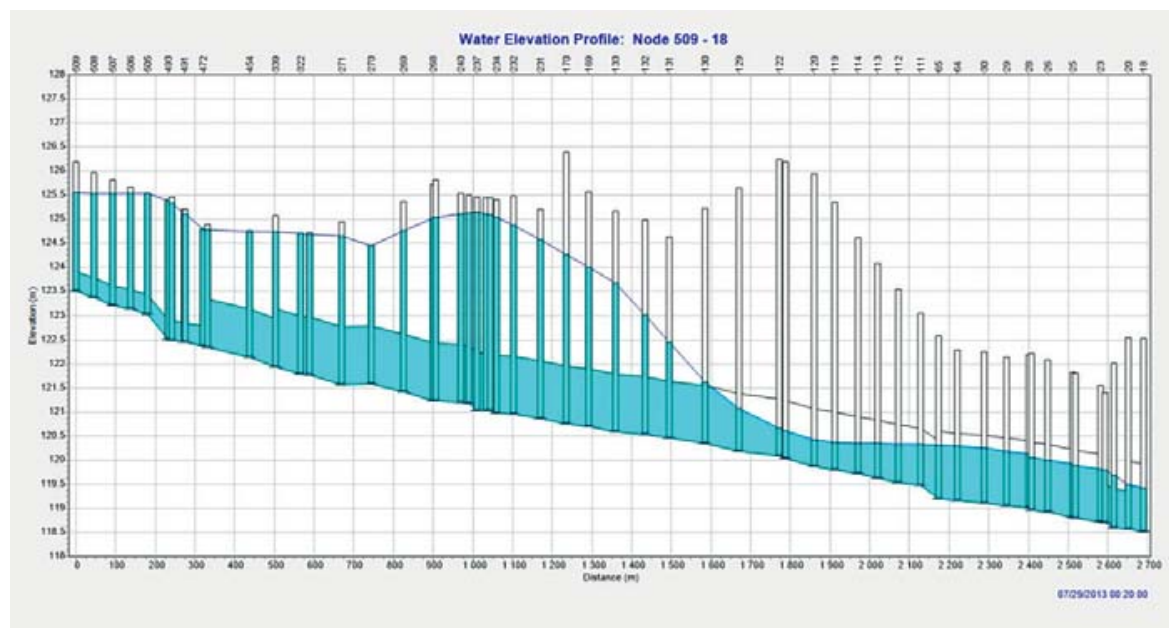

Fig. 6. Collector profile at the time of the largest overflow during precipitation of $C=5$ years

\section{Summary and final conclusions}

Hazards for drainage systems are triggered both by climatic factors (growth in air temperature and precipitation intensity) and non-climatic factors. Environmental transformations of today's cities under the effect of urbanisation and industrialisation cause changes in water balance. Therefore, climate change is affected by a number of processes, such as business operations and the occupancy of new areas for development, including those particularly sensitive to the effects of climate changes, (e.g. flood areas). The proportion of impermeable surfaces is also growing in areas that are already developed.

The paper presents contemporary dimensioning standards of area drainage systems. Hazards for drainage systems arising from climate change have been discussed. Trends of changes in the precipitation structure have been presented on the example of data from Wroclaw. The need for changes in precipitation scenarios has been indicated for modelling overflow in channels and a research methodology and assessment criteria have been proposed to assess the degree of reliability of the drainage system. Sample results of the analysis of the operation of the rainwater drainage system in the Gaj and Tarnogaj housing estates in Wroctaw have been presented - this analysis was conducted on a calibrated hydrodynamic model in SWMM software. The degree of flooding and the specific flood volume have been used as the assessment criteria for system overload. It has been proved that the examined system does not meet the PN-EN 752:2008, DWA-A 118:2006 and Merkblatt no. 4.3/3:2009 standards and requires adaptation to climate changes.

To sum up, it should be emphasised that with the today's dimensioning of newly built drainage systems (and the modernisation of existing systems), it becomes necessary to take the forecast climate changes into consideration in the future. Therefore, safe dimensioning methods of rainwater drainage networks and structures should be used (MMN, according to [6]) and their operational reliability should be examined using hydrodynamic modelling. 
The identification of potential system overloads already justifies the need to prepare new remedial actions for example, those consisting of the modernisation of the drainage infrastructure, such as the construction of relief channels and storage-infiltration reservoirs, and the raising of roadside curbs or the embanking of specific areas $[6,10-14,23,34]$.

This work has been completed as part of the statutory activity of the Department of Environmental Engineering, Wroctaw University of Science and Technology, financed from the funds of the Ministry of Science and Higher Education in the period 2016-2017.

\section{References}

[1] Ministerstwo Środowiska, Projekt VI Raportu Rządowego oraz Raportu dwuletniego dla Konferencji Stron Ramowej Konwencji NZ w sprawie zmian klimatu, Warszawa 2013.

[2] IPCC: The Physical Science Basis, Cambridge University Press, 2007.

[3] IPCC: Impacts, Adaptation, and Vulnerability, Cambridge University Press, 2014.

[4] Landerink G., Van Meijgaard E., Increase in hourly precipitation extremes beyond expectations from temperature changes, Nature Geosci, 2008, No. 1, 511-514.

[5] Kundzewicz Z. W., Zmiany ryzyka powodziowego w Europie, Symposium Paris - Orlean 28-30.03.2012, 11-20.

[6] Kotowski A., Podstawy bezpiecznego wymiarowania odwodnieńterenów, Sieci kanalizacyjne (Tom I); Obiekty specjalne (Tom II), Wydawnictwo Seidel-Przywecki (Edition II), Warzsawa 2015.

[7] PN-EN 752:2008: Drain and sewer systems outside buildings.

[8] Kotowski A., Kwantyfikacja problemuzmian klimatu w projektowaniu infrastruktury wodnokanalizacyjnej miast, Wydawnictwo Politechniki Lubelskiej, Lublin 2014, 177-189.

[9] Arbeitsblatt ATV-A1 18:2006: Hydraulische Bemessung und Nachweis von Entwässerungssystemen, DWA, Hennef 2006.

[10] Geiger W., Dreiseitl H., Nowe sposoby odprowadzania wód deszczowych, Wydawnictwo Projprzem-EKO, Bydgoszcz 1999.

[11] Bolt A., Burszta-Adamiak K., Gudelis-Taraszkiewicz K., Suligowski Z., Tuszyńska A., Kanalizacja. Projektowanie, wykonanie, eksploatacja, Wydawnictwo Seidel-Przywecki, Warszawa 2012.

[12] Królikowska J., Królikowski A., Wody opadowe. Odprowadzanie, zagospodarowanie, podczyszczanie i wykorzystanie, Wydawnictwo Seidel-Przywecki, Warszawa 2012.

[13] Królikowska J., Królikowski A., Żaba T., Kanalizacja. Podstawy projektowania, wykonawstwa i eksploatacji, Wydawnictwo Politechniki Krakowskiej, Kraków 2015.

[14] Edel R.,SuligowskiZ., Wplyw parametrów wpustów deszczowychnasprawnośćodwodnienia powierzchniowego dróg i ulic, Wydawnictwo Politechniki Gdańskiej, Gdańsk 2004.

[15] Nowakowska M., Kaźmierczak B., Wartalska K., Kotowski A., Budowa modelu hydrodynamicznego skanalizowanej zlewni deszczowej we Wroctawiu, GWiTS 2017, No. 4, 189-195. 
[16] Nowakowska M., Kotowski A., Metodyka i zasady modelowania odwodnień terenów zurbanizowanych, Oficyna Wydawnicza Politechniki Wrocławskiej, Wrocław 2017.

[17] Bogdanowicz E., Stachý J., Maksymalne opady deszczu w Polsce. Charakterystyki projektowe, Materiały badawcze, Seria: Hydrologia i Oceanologia, No. 23, IMGW, Warszawa 1998.

[18] Pińskwar I., Projekcje zmian w ekstremach opadowych $w$ Polsce, Wydawnictwo Komitetu Gospodarki Wodnej PAN, No. 32, Warszawa 2010.

[19] Willems P., Revision of urban drainage design rules based on extrapolation of design rainfall statistics, 12th Int. Conf. on Urban Drainage, Porto Alegre, 11-16 September 2011.

[20] Larsen A.N., Gregorsen I.B., Christensen O.B., Linde J.J., Mikkelsen P.S., Potential future increase in extreme one-hour precipitation events over Europe due to climate change, Water Science Technology 2009, Vol. 60, 2205-2216.

[21] Staufer P., Leckebusch G., Pinnekamp J., Die Ermittlung der relevanten Niederschlagscharakteristik für die Siedlungsentwässerung im Klimawandel. Korrespondenz Abwasser, Abfall 2010 (Jg. 57), No. 12.

[22] Merkblatt Nr. 4.3/3, Bemessung von Misch- und Regenwasserkanälen, Teil 1: Klimawandel und möglicher Anpassungsbedarf, Bayerischen Landesamtes für Umwelt (Referat 66) 2009.

[23] Dąbrowski W., Dąbrowska B., Przewidywany wplyw zmian klimatu na dysfunkcję systemów odprowadzania ścieków, GWiTS 2012, No. 1, 17-20.

[24] Kotowski A., Prognozowane skutki ocieplenia klimatu w modelowaniu przeciążeń systemów kanalizacyjnych $w$ Polsce, GWiTS 2013, No. 5, 201-205.

[25] Kaźmierczak B., Kotowski A., The influence of precipitation intensity growth on the urban drainage systems designing, Theoretical and Applied Climatol. 2014, Vol. 118, No. 1, 285-296.

[26] Kotowski A., Kaźmierczak B., Dancewicz A., Modelowanie opadów do wymiarowania kanalizacji, Wydawnictwo KILiW PAN, Studia z zakresu Inżynierii, No. 68, Warsaw 2010.

[27] Kotowski A., Kaźmierczak B., Probabilistic models of maximum precipitation for designing sewerage, Journal of Hydrometeorology 2013, Vol. 14, No. 6, 1958-1965.

[28] Siekmann M., Pinnekamp J., Indicator based strategy to adapt urban drainage systems in regard to the consequences caused by climate change, 12th Int. Conf. on Urban Drainage, Porto Alegre, 11-16 September 2011.

[29] Schmitt T. G., Risikomanagement statt Sicherheitsversprechen, Korrespondenz Abwasser, Abfall 2011, No. 1, 40-49.

[30] Zawilski M., Niestandardowe wykorzystanie GIS w modernizacji systemów kanalizacyjnych, GWiTS 2009, No. 6, 34-36.

[31] Kaźmierczak B., Kotowski A., Weryfikacja przepustowości kanalizacji deszczowej $w$ modelowaniu hydrodynamicznym, Oficyna Wydawnicza Politechniki Wrocławskiej, Wrocław 2012.

[32] Kotowski A., Kaźmierczak B., Nowakowska M., Analiza obciażenia systemu odwadniania terenu w przypadku prognozowanego zwiększenia częstości i intensywności deszczów z powodu zmian klimatycznych, Ochrona Środowiska 2013, Vol. 35, No. 1, 25-32. 
[33] Nowakowska M., Identyfikacja parametrów hydrologicznych i hydraulicznych zlewni miejskiej w modelowaniu hydrodynamicznym SWMM, PhD dissertation. Faculty of Environmental Engineering Wrocław University of Technology, Wrocław 2016.

[34] Licznar P., Wymiarowanie zbiorników retencyjnych ścieków deszczowych na podstawie syntetycznych szeregów czasowych opadów deszczu, Ochrona Środowiska 2013, Vol. 35, No. 2, 27-32. 